\title{
Transformative Contextual Realism
}

\author{
Manon Westphal ${ }^{1}$
}

Accepted: 18 October 2021 / Published online: 17 November 2021

(C) The Author(s) 2021

\begin{abstract}
Realist political theory is often confronted with the objection that it is biased towards the status quo. Although this criticism overlooks the fact that realist political theories contain various resources for critique, a realist approach that is strong in status quo critique and contributes, constructively, to the theorising of alternatives to the status quo is a desideratum. The article argues that contextual realism, which sources its normativity from particular contexts, harbours an underexploited potential to establish such a form of political theorising. By drawing on ideas and principles that have guided critical engagements with social and political forms in a particular context, and on widely shared views of need for reform, realists can identify deficits of the status quo and contribute to a debate on how these deficits might be addressed. This article describes and illustrates the idea of a transformative contextual realism, and defends it against some potential objections.
\end{abstract}

Keywords Context $\cdot$ Critique $\cdot$ Normativity $\cdot$ Political reform $\cdot$ Realism $\cdot$ Status quo

\section{Introduction}

This article proposes a novel way of doing realist political theory, which I dub transformative contextual realism. It contributes to the ongoing debate on possibilities for realists to distance themselves from the status quo and shows that possibilities to do realist political theory with the aim of providing orientation for changes to the status quo can be expanded if realists use contexts differently for their theorising than to date.

Current work in political theory that seeks to do normative political theory realistically often faces the objection that it is an unambitious normative enterprise: as an effect of their wish to recognise the "autonomy of the political" (Rossi and Sleat 2014: 690), realists fail to show how things could be better than they are (e.g. Erman and Möller 2018; McQueen 2019). If realism were indeed tied to the status quo, that would severely limit its capacity to

Manon Westphal

manon.westphal@uni-muenster.de

1 University of Münster, Münster, Germany 
address questions that occupy people in real politics. After all, politics is often not just about preserving what there is, but about changing things for the better (even if there is disagreement about what better means). However, those who charge realism with a status quo bias often overlook the critical potential of realist political theory (Cross 2020; Finlayson 2017) and neglect the diversity of approaches in realist political theory (Rossi 2019). Especially those realists who can be grouped under the label radical realism have shown that realism need not be faithful to the status quo. Raymond Geuss, to whose work many radical realists refer, argues that political theory should not only help people understand a given situation, but also evaluate it and, in addition, provide orientation for how to proceed from a given situation (Geuss 2008: 40). Among the possibilities for political theorists to contribute to the identification and treatment of problems of the status quo are conceptual innovation (Geuss 2008: 43-44) and the critique of ideologies that stabilise the status quo (Geuss 2008: 50).

Radical realists who build on Geuss's work elaborate what it may mean to do realist political theory as ideology critique (Prinz 2016; Prinz and Rossi 2017; Rossi 2019) and argue that realism does not rule out utopian ideas and radical political proposals (Raekstad 2018, 2020, 2021; Rossi 2019). However, possibilities to do radical realism, understood as a form of realist political theory that makes the status quo an object of critique, have not yet been fully exploited. One question that deserves more attention is how realists might contribute to the task of providing orientation by developing ideas on how the status quo could be improved. Current work on realism and utopianism deals with the question if (some) utopian ideas are compatible with realism, rather than with the question how realists might themselves produce considerations on possibly attractive directions of change. Meanwhile, ideology critique limits itself to debunking the status quo. I am not suggesting that political theory can provide orientation only by determining possibly attractive directions of change. Clearly, that is not the case. Ideology critique, which removes appearances of the status quo as natural, can encourage people to view their situation differently and to start thinking about alternatives to the status quo. But the portfolio of possibilities for realists to provide orientation would be expanded in a fruitful way if they also contributed, constructively, to the identification of possibilities for change that could help surmount the status quo in desirable directions.

A central challenge that this endeavour faces is to demonstrate how realists can theorise possible reforms without using moralist forms of argumentation. Some commentators suggest that avoiding moralism means isolating normative argumentation from moral considerations (Leader Maynard and Worsnip 2018; Erman and Möller 2015), but this understanding rests on a misconception of the realist project (Hall and Sleat 2017: 290; Jubb 2019: 362; Prinz 2020: 80; Sleat 2014: 319, 2016; Thomas 2017: 304). Realists argue that moral considerations do not necessarily take precedence over other considerations in politics (Horton 2010: 440; Philp 2012: 636; Sleat 2013: 65, quoting Newey 2001: 106-107), and some argue that political norms are independent from the norms of a personal morality (Rossi 2010: 506), but realists do not picture the political as a realm devoid of morality. Thus, when realists argue that political theory should be non-moralist and recognise the autonomy of the political, they do not seek exclusive uses of non-moral normative resources. Instead, they demand that political theorists abandon abstract forms of ethical argumentation and develop normative arguments through engagements with the particularities of political practice (Finlayson 2017: 266; Galston 2010: 387-388). There is no agreement among realists about what it means to realise that general programmatic claim, and some commentators take the 
diversity of interpretations in the debate as a reason to speak of a "family" of realist political theories rather than one unified approach (e.g. McQueen 2017: 301). By describing how different approaches to realist political theory-ordorealism, radical realism (as ideology critique) and contextual realism - source normativity from political practice, Enzo Rossi (2019) gives a helpful overview of important differences among members of that family. I want to briefly review the differences here to show why elaborating the potentials of contextual realism represents a promising possibility to develop radical realism in the desired direction.

Ordorealism derives its normativity from a consideration of the tasks that characterise politics as a distinct social practice, among which "the provision of order and stability" (Rossi 2019: 642) plays a central role. Radical realism, which Rossi uses synonymously with ideology critique, "acquires its normativity by contesting what one may call legitimation stories" (Rossi 2019: 642). It addresses the truth claims that are involved with political practices and unmasks their ideological nature. Contextual realism derives its normativity from an "interpretation of the point and purpose of particular political practices" (Rossi 2019: 642).

Attempts to elaborate the constructive side of radical realism cannot rely on ordorealism or on ideology critique. The strategy of sourcing normativity through negative critique endows ideology critique with an unlimited capacity to criticise the status quo, but it also renders it ill-equipped to ground positive views of what might be desirable to put in place once a need for reform is identified. Ordorealism, on the other hand, is clearly vulnerable to the status quo bias objection. It enables realists to criticise situations where order and stability are absent, but it does not tap into normative resources that could guide critical assessments of the status quo wherever, and through whatever means, order and stability are preserved. ${ }^{1}$

Contextual realism enables realists to go beyond ordorealism's narrow focus on order and stability. If realists do not ask what characterises politics as a distinct type of social practice, in general, but consider the particular practices of a given context, they can tap into a richer pool of normative resources. The normative considerations that influence the political practices in particular contexts are more diverse, and often more demanding, than the slim set of norms sourced by ordorealism. People usually want politics to achieve more than preserve order and stability. Thus, obtaining normative resources from engagements with particular contexts is a possibility for realists to expand their resources for critique in ways that might enable them to criticise the status quo, also in situations where order and stability are in place. To be sure, the normative resources of a context can also be part of the status quo, understood broadly, in the sense that they exist here and now. However, when I speak of the status quo, I mean the social and political institutions and dominant social and political practices in a given situation. The broader social context of such institutions and practices may contain ideas and norms that can serve as a basis for criticising them, and it may also contain social practices that more or less directly challenge them. In that

\footnotetext{
${ }^{1}$ It is important to note that, while Hobbes can be called a fully fledged ordorealist, hardly any contemporary realist is a pure ordorealist. Bernard Williams's theory, which emphasises the need for order as a response to the "first political question", also contains elements of contextual and radical realist argumentation (Rossi 2019: 641-642). Ordorealism, contextual realism, and radical realism should thus be understood as different logics of realist political theorising that realists may combine.
} 
sense, context is not identical with the status quo and may harbour a potentially rich pool of resources for criticising it.

The contextual strategy of sourcing normativity through an "interpretation of the point and purpose of particular political practices" (Rossi 2019: 642) might enable theorists to engage in constructive critique. Once they have obtained normative resources from a particular context, the uses of such resources need not be limited to negative critique. Where theorists determine deficits of the status quo on the basis of the relevant resources, they might as well theorise possible directions of change that reflect the content of those resources. The interesting question of course is how this might be done, and the aim of this article is to offer a response to that question. At this point, I only want to highlight that attempts to elaborate a constructive radical realism should probe the contextual strategy of sourcing normative considerations for their theorising: in contrast with ideology critique, it is not bound to a debunking stance, and in contrast with ordorealism, it is not limited to standards that relate to the general features of politics as a distinct social practice.

In developing my case for transformative contextual realism, I will proceed as follows. First, I describe the general idea of the approach and contrast it with other forms of contextual argumentation in the broader field of realist political theory. Second, I illustrate the proposed approach by means of an example. Third, I address potential objections to my argument, which might be raised from different directions, i.e. from those who might think that transformative contextual realism succumbs to moralist argumentation, on the one hand, and from radical realists who favour ideology critique as a way of doing realist political theory, on the other.

\section{Radicalising Contextual Realism}

I submit that the critical potential of contextual realism can be exploited to a fuller extent than to date if theorists consider contextual resources of two sorts, namely ideas and principles that have been guiding critical engagements with social and political forms in a particular context, and demands for change that are widely shared in that context. On the basis of resources of the first sort, theorists can identify aspects of the status quo that can be deemed problematic and in need of change. On the basis of resources of the second sort, they can produce contributions to a debate on possible reforms of the status quo that might help cure the identified problems. Thus, the basic idea of transformative contextual realism, as I dub the form of contextual realism that uses contextual resources accordingly, is that contexts often contain resources that do not support and stabilise the status quo, but provide a basis for criticising it. It is by drawing on such resources that theorists can exercise a potentially fundamental critique of the status quo that is both negative and constructive. It is also non-moralist to the extent that neither the aspects of the status quo that are deemed problematic, nor the considerations on possible changes of the status quo, are determined through abstract moral argumentation, but through engagements with ideas and principles that have been influencing actual social and political developments as well as with what people actually think would be desirable to change about the status quo.

Before I illustrate the idea of transformative contextual realism and give more flesh to it, I want to show how it distinguishes the proposed approach from current forms of contextual argumentation in the broader field of realist political theory. A number of members of 
the realist family have elaborated forms of contextual realism. I focus on three approaches here: Bernard Williams's theory of political legitimacy, which has been further developed by Robb Jubb, John Horton's modus vivendi theory, and Jonathan Floyd's normative behaviourism. The selection is not exhaustive, but it allows me to contrast the approach I am proposing with some of the most relevant and interesting approaches to contextual realist political theory. I will describe the main ideas of these three contextual approaches and show that, although all three demonstrate how contextual argumentation enables realists to move beyond the normatively toothless project of ordorealism, transformative contextual realism might be especially attractive for those who seek to exploit the capacities of realist political theory to distance itself from the status quo.

Bernard Williams argues that legitimate regimes must deliver more than "order, protection, safety, trust, and the conditions of cooperation" (Williams 2005: 3). In addition, they must meet the Basic Legitimation Demand (BLD), which means that political rulers must offer a justification of their rule that makes sense to those who are subject to that rule. The argument is contextual to the extent that Williams stresses that what makes sense to people as a "structure of authority" (Williams 2005: 10) differs from context to context. Today, legitimate states must have a liberal form, but that does not mean that liberal states meet the BLD generally better than other regimes. The nub of Williams's argument is that, in the context of modernity, which is characterised by particular "organizational features (pluralism, etc., and bureaucratic forms of control), individualism, and cognitive aspects of authority (Entzauberung)" (Williams 2005: 9), non-liberal legitimation stories simply no longer make sense to people. Williams's famous formula "LEG + Modernity = Liberalism" (Williams 2005: 9) is thus the product of a genuinely contextual argument about the normative content of political legitimacy.

Robert Jubb builds on Williams's line of argumentation and shows that a contextual specification of legitimacy need not be limited to a general commitment to liberalism. He argues that a realist conception of legitimacy can include a "threshold set of egalitarian commitments" (Jubb 2015: 679), because a case for egalitarianism need not be based on the moralist view that distributive justice is an intrinsic value that should be respected everywhere (see also Jubb 2017). For Jubb, the relevant observation is that people who suffer harms caused by a grossly unequal distribution of goods have little reason to accept the authority of the regime that is responsible for such harms. Thus, like Williams, Jubb grounds his theory of legitimacy on an interpretation of what makes sense to people as a justification of political rule in the context of modernity. "At least under contemporary conditions, a political order that routinely subjects some of its members to the kinds of status harms on which non-intrinsic egalitarianism focuses cannot offer the objects of that disrespect a full explanation of why they ought to accept it" (Jubb 2015: 684).

Some critics of realist theories of legitimacy argue that realists would place "several of today's most suppressive regimes above the threshold" (Erman and Möller 2018: 526). That is an exaggerated assessment. Regimes that lack liberal institutions, or fail to create a basic level of distributive equality, can be criticised on the basis of Williams's and Jubb's theories. I argue elsewhere that contextual argumentation allows realists to include the provision of possibilities for contestation into their set of standards of legitimacy (Westphal forthcoming). Nevertheless, possibilities to criticise the status quo on the basis of a set of standards that regimes must meet, in order to fall into the category of forms of political rule that can make sense to people as a "structure of authority" (Williams 2005: 10) under contemporary 
conditions, are severely limited. Demanding that regimes be broadly liberal, guarantee a basic level of distributive equality, or allow people to have a say in politics, means to deem legitimate a potentially great range of situations, including some that are unjust, or otherwise problematic, which leaves theorists without resources to criticise the status quo, at least in many cases.

To be clear, I neither claim that the capacity to provide a basis for a critique of the status quo is the most important measure of the quality of a realist political theory, nor that a limited capacity to ground a critique of the status quo is necessarily characteristic of all realist theories of legitimacy. What I am interested in here is the particular way in which the considered theories source their normativity from context. Williams and Jubb consider structural features of modern societies and widely shared views of what basic achievements of political rule must be. These features and views certainly limit the range of regimes whose claim to political authority could realistically make sense to people today, but they leave that range so broad that many political regimes fall into it. There might indeed be good reasons for realist theorists of legitimacy to remain faithful to this way of using contextual resources for their theorising. ${ }^{2}$ But those realists who seek to fathom the capacities of contextual argumentation to serve the undertaking of a radical realist political theory might want to look to other possibilities.

John Horton's modus vivendi theory and Jonathan Floyd's normative behaviourism shift the focus more directly to actions: both are interested less in the criteria of legitimation stories that make sense to people in the context of modernity, than in how people actually act. Again, I can set out only the main ideas of the approaches here.

Horton uses the term modus vivendi to characterise political arrangements that avoid "serious civil disruption" and maintain "a level of social order that is at least sufficient to enable the parties subject to it to live minimally worthwhile lives" (Horton 2010: 438). In addition, a modus vivendi arrangement must be "broadly 'acceptable' or 'agreeable' to those who are party to it" (Horton 2010: 439). While the first part of this characterisation reflects the normative content of ordorealism, the second endows modus vivendi theory with a capacity to criticise a greater range of situations than those that fail to create peace and order. A regime that is not accepted by the ruled, fails the standards of modus vivendi. The contextual nature of the theory shows itself in Horton's answer to the question how it can be determined whether a particular political arrangement is acceptable. That question should be answered, Horton argues, by considering particular contexts and by examining not only what people "say or claim" but also how they act (Horton 2019: 140). If people participate in the normal political processes, take advantage of the benefits that are provided by the existing arrangement, or make recourse to the judicial system, such forms of behaviour should be read as evidence that they accept that arrangement (Horton 2019: 140).

Jonathan Floyd takes a similar stance when he argues that "certain political actions do sometimes speak more clearly than certain moral thoughts" (Floyd 2011: 60). The basic idea of his normative behaviourism is that actions can serve as resources for normative

\footnotetext{
${ }^{2}$ For instance, a theory of legitimacy that determines more demanding standards, such as the radical levelling of inequalities rather than a "threshold set of egalitarian commitments" (Jubb 2015: 679), would tend to determine disputed policies as standards of legitimacy. Such a theory might be ill-equipped to mirror an important fact about political practice, which is that even fundamental disagreements over policies are often processed without the involved parties questioning the political authority of the regime, or making their willingness to accept the regime's right to rule dependent on whether or not their particular policy preferences are realised.
} 
argumentation to the extent that they represent people's "verdicts" on the political system in which they live (Floyd 2020: 139). More specifically, Floyd argues that two types of action, and the normative verdicts that they express, are particularly relevant for the evaluation of political systems, namely insurrection and crime (Floyd 2017: 168, 2020: 139). Insurrection and crime express negative verdicts on the political system that have a special quality in the sense that "people tend only to partake of them when they find their current lives unbearable, due to a lack of various goods" (Floyd 2020: 140). Crudely, the idea of normative behaviourism is that the quality of regimes can be measured on the basis of how much of these actions they produce (Floyd 2017: 169). Because empirical evidence shows that egalitarian liberal democracies produce less insurrection and less crime than other political systems, the argument amounts to a "pseudo-empirical justification" of egalitarian liberal democracy (Floyd 2020: 140).

These action-centred forms of contextual realism clearly harbour a potential to guide a critique of the status quo that goes beyond that of ordorealism. Where people openly confront the normal processes and institutions, or withdraw from them, modus vivendi theorists would identify a decrease of acceptance that diminishes the legitimacy of the political arrangements. Where insurrectionary activities and crime increase, normative behaviourists would identify a deterioration of the situation that makes reforms recommendable, independent of whether or not the regime that is in place is a broadly liberal one.

However, radical realists should not be satisfied with limiting their normative resources to the described actions. As Floyd stresses, insurrection and crime are special sorts of action in the sense that they involve a high level of "personal risk" (Floyd 2020: 140). Something very similar applies to the actions that Horton centres on - people certainly face risks and costs when they confront the existing institutions, or withdraw from them, and forego the benefits that they provide. One might think that the risk character of such actions renders them particularly strong indicators of people's negative views of the relevant status quo, because people would not engage in them if they did not find their circumstances unbearable. But if realists limited their resources for critique to such sorts of actions, they would lack the means to criticise a great range of situations. People might have all sorts of reasons not to partake in crime, insurrection, confrontation, or withdrawal. Such actions might be absent, or not frequently used, for instance because people feel powerless or incapable of standing a confrontation, or because they do not think that such actions would be right, or help them improve the situation in meaningful ways. Thus, while it may be true that the presence of actions of the sorts that Horton and Floyd describe can tell us something important about the deficient character of a given situation, the absence or infrequent uses of such actions do not reliably indicate that the status quo is in a good condition. It might be that people find their circumstances deeply unjust, or otherwise problematic, and yet, for reasons such as those mentioned, do not partake in such actions.

I conclude that current forms of contextual argumentation in the broader field of realist political theory demonstrate the potential of contextual realism to identify normative resources that expand possibilities for critique beyond the rather narrow possibilities of ordorealism, but that they do not provide a sufficient basis for a radical realist political theory. For radical realists, who consider critical engagements with the status quo a central task of political theory, it is important to be open to the possibility that something might even be problematic about political arrangements that do not contradict structural features of modern societies and do not produce high levels of insurrection, crime, confrontation, 
or withdrawal. Because most contemporary democracies meet these criteria, at least those radical realists who want to make contemporary democracies objects of their theorising need other normative resources for argumentation than those sourced by the theories considered in this section.

I argue that transformative contextual realism determines such resources and shows how they can be used to theorise possible changes to the status quo. By considering ideas and principles that have been guiding critical engagements with social and political forms in a particular context, political theorists can identify deficits of the status quo that require reform, even if the existing political arrangements do not seem problematic on the basis of the standards determined by the current forms of contextual realism. By considering demands for change that are widely shared in a particular context, theorists can contribute to a debate about desirable possibilities to change the status quo. What renders such possibilities desirable is not that they express some abstractly specified moral principle, but that they can help overcome, or at least mitigate, the deficiencies of the status quo that are identified on the basis of contextual normative resources, and speak to demands for reform that are widely shared in that context.

\section{Doing Transformative Contextual Realism}

This section illustrates what it may mean to do transformative contextual realism. The particular context that I refer to here is that of contemporary western democracies. This choice does not rest on the assumption that this context is more relevant or interesting than others. Rather, it allows me to substantiate my claim that transformative contextual realism is suited to contribute to critical assessments of those regimes that would not appear too deficient if assessed solely on the basis of the standards determined by current forms of contextual realism.

Throughout the history of western democracies, many political changes of social and political institutions, whose outcomes are now widely seen as positive achievements and even necessary features of a democratic society, were driven by the "democratic principle of liberty and equality" (Laclau and Mouffe 2001: 154-155). Rather than a name for a particular form of social order, the democratic principle is a narrative, or a "social imaginary" (Laclau and Mouffe 2001: 155), that provides an evaluative measure for the interpretation of unequal social and political forms as instances of injustice or oppression that should be overcome. The democratic principle does not create hostility to all forms of inequalityclearly, there are many forms of inequality in the contexts of western democracies that are not (permanently) scandalised - but it endows these contexts with a normative resource for critique that can always be activated for a politicisation of unequal social and political forms. Historical examples of such a politicisation are the workers' movement, which politicised the subordinated status of workers in capitalist society, and the feminist movement, which politicised, among other things, the exclusion of women from the right to vote. Both of these movements fought political struggles for reforms that eliminated or mitigated the identified ills - workers' rights and welfare state measures in the former case and suffrage for women, among other measures, in the latter. A current example of a movement that politicises social inequalities through the lens of the democratic principle is the LGBTQI+ movement, one 
of whose recent political successes was the abandonment of the heterosexual monopoly of access to the legal institution of marriage.

The contexts of western democracies of course contain diverse normative resources, but the democratic principle is an especially important one regarding the role it has played in the dynamics of political change in those contexts as well as regarding the meaning it has for the normative self-understanding of democratic societies. Thus, when transformative contextual realists ask what ideas and principles have been guiding critical engagements with social and political forms in the contexts of western democracies, the democratic principle is a particularly pertinent candidate, although it may not be the only one.

The question that a transformative contextual realist who uses the democratic principle as a normative resource for evaluating the status quo asks is: what elements of the status quo in western democracies appear problematic if assessed on the basis of the democratic principle? Because the democratic principle represents a normative narrative that influences how people view and assess social and political forms but, as such, does not have a fixed meaning or determined set of targets, transformative contextual realists do not answer that question by determining what particular aspects of social relationships should be interpreted as instances of oppression. For example, they do not argue that the inequalities of income and wealth in western democracies are more important objects of critique than cultural inequalities, or the other way around. Instead, they look to the institutions of political decision-making, with which citizens deal with their disagreements and make common decisions ordering social life, and consider if these institutions operate in ways that facilitate the articulation and political processing of views and demands that are driven by the democratic principle. Where there is evidence that the institutions of political decision-making impede rather than facilitate attempts to politicise social and political inequalities, transformative contextual realists diagnose a need for reforms that might help overcome these impediments.

Strong evidence of political decision-making processes operating in ways that impede the politicisation of unequal social and political forms is if these processes are biased against groups of society that are disadvantaged by social hierarchies. The unequal responsiveness of political decisions in western democracies is a prime example of such evidence. Studies by political scientists that investigate to what extent policy decisions reflect the policy preferences of different socioeconomic groups show that policy decisions in the US and in European democracies advantage the preferences of citizens with a higher income and better education and disadvantage the preferences of citizens from lower socioeconomic strata (e.g. Elsässer et al. 2018; Erikson 2015; Gilens 2005; Peters and Ensink 2015). A more encompassing picture of the biases of political decision-making processes would of course have to consider not only socioeconomic criteria. However, what the socioeconomic bias of political responsiveness shows is that, in today's democracies, political decision-making processes serve as a means for the better-off to protect their interests rather than as a means for the disadvantaged to articulate their interests and the grievances about the status quo that they may have. The transformative contextualist realist does not speculate what political decisions would look like if that bias were absent, but highlights that the very presence of that bias indicates that political decision-making processes currently operate in ways that impede the politicisation of unequal social forms. This feature of the status quo requires reform, not by virtue of a universal, abstractly defined moral idea, but by virtue of the democratic principle, as an important part of what, in the context of western democracies, political processes are expected to facilitate. 
Arlen and Rossi have recently argued that a realist democratic response to the oligarchic tendencies in contemporary democracies could take inspiration from John McCormick's (2011) proposal to revive the Roman tribunate model. Polities should incorporate "an interconnected set of plebeian assemblies" (Arlen and Rossi 2021: 42) that is composed of non-wealthy citizens selected by lottery, endow these assemblies with veto and referenda proposing power, and task them with reviewing political activities in policy areas where "massive concentrated wealth can be deployed for discretionary public influence" (Arlen and Rossi 2021: 41). An institution of this sort might indeed ensure a fairer political visibility and influence of the views and interests of citizens from lower socioeconomic strata. An update of the tribunate that takes into account the particularities of current social divisions and the structural features of modern politics could transform that institutional model into a contemporary proposal for institutional innovation with the capacity to reform decisionmaking processes in ways that help mitigate the responsiveness bias of political decisions. Transformative contextual realism, however, sources ideas on what might be potentially effective reform measures by looking to demands for reform that are already widely shared by those living in the context in question. More specifically, it centres on widely shared demands for reform that seek changes to the status quo that might effectively counteract the identified deficit of the status quo, which is the responsiveness bias of political decisionmaking in my argument.

To illustrate what this might mean, I refer to the debate on campaign finance reform in the United States. An overwhelming majority of US citizens observe "that legislators are more attentive to wealthy donors than voters" and "want their representatives to cross party lines in order to reduce the influence of money in politics" (Mazo and Kuhner 2018a: 2). At the same time, there is a considerable lack of "practical solutions for reform", which has much to do with how the Supreme Court jurisprudence has narrowed possibilities for campaign finance reform (Mazo and Kuhner 2018a: 8-10). People may of course have different reasons to consider the influence of money on political campaigning problematic, but it seems obvious that a reduction of that influence would render the political process more open to, and possibly more responsive to political projects driven by the democratic principle. Because current campaign finance rules allow a small number of wealthy donors, who "tend to be significantly more conservative on economic issues, in their views on government spending on social programs, and on issues like affirmative action" (Mazo and Kuhner 2018a: 6-7), to exercise a disproportionate influence on candidates, officeholders, and legislative decision-making, campaign finance rules contribute to a perpetuation of the unequal responsiveness of political decision-making. The widely shared demand to reduce the role of money in politics thus falls into the category of demands for reform that the transformative contextual realist seeks to take up. Because the demand for campaign finance reform coexists with a considerable lack of ideas for practical solutions in the current situation, this debate is a prime example of a situation where political theorists, possibly in collaboration with scholars from other disciplines, could make meaningful contributions to a search for reform measures on the part of political actors who seek to translate that demand into concrete political projects.

Before I show, by means of examples, what such contributions might look like, it seems useful to consider at least briefly what the relevant expertise of other disciplines might be. Mazo and Kuhner's volume (2018b) impressively shows legal scholars can sound out the legal terrain to describe reform measures that could be implemented in the current situation, 
ranging from the possibility to overturn the Supreme Court jurisdiction to measures that would work within the confines of that jurisdiction. Political scientists and social movement researchers could provide insights into the practical challenges that politicians and political activists face when they try to mobilise support for particular reform measures. For instance, findings on the strategies and contextual conditions that have contributed to the success or failure of different sorts of demands for political reform in other cases might be relevant for political actors who need to make decisions on how they want to push the political debate on campaign finance reform forward. In the context of what might thus be an overall multidisciplinary endeavour, the distinct expertise of political theorists concerns the clarification of the political meaning and normative implications of possible reform measures. Transformative contextual realists expose and organise relevant characteristics of different possible reform measures. They refrain, however, from ranking reform measures in terms of better and worse, which is a task that they leave to the practical judgements of political actors.

For illustrative purposes, consider three options for campaign finance reform that could be undertaken to limit the role of money in politics: (a) overturning Citizens United v. Federal Election Commission ${ }^{3}$ with a constitutional amendment that would "allow federal, state, and local governments to set limits on fundraising and spending in elections" (Fein 2018: 370), (b) deterring third party spending in electoral races by means of private contracts among opposing campaigns, "in which each campaign agrees to be penalized from its own campaign treasury for any spending from an outside group that supports the candidate" (Sitaraman 2018: 201), and (c) changing corporate law to make corporations "import democratic norms within their governance structure" (Greenfield 2018: 241-242). These reform options do not just exploit different legal possibilities, but also differ significantly regarding their political meaning and normative implications. I will indicate some of the differences to illuminate how transformative contextual realists could clarify and organise relevant differences of possible reform options, in order to provide potentially helpful orientation for political actors who think it would be important to limit the role of money in politics and need to make decisions on how to act in a situation where several options for reform might serve that goal.

Reform option (a) differs from (b) and (c) in the sense that it does not by itself represent a specific policy solution but, instead, aims to broaden possibilities for reform. A constitutional amendment would "lay the foundation for further reforms" (Fein 2018: 370), because it would enable political processes unhampered by Citizens United and thus create a political situation where a greater range of reform paths would be open to political decisionmakers, including the sort of stricter limitations of campaign funding that Citizens United declared unconstitutional. Relatedly, the constitutional amendment solution is distinct in the sense that it would expose the political nature of constitutional law, i.e. the fact that higher law, which limits normal politics, is ultimately contestable and changeable by democratic decisions. The constitutional amendment solution would give expression to democratic sovereignty in a more fundamental sense than the other two reform options, because the particular change of the status quo that it would put in place would decide the conflict between

\footnotetext{
${ }^{3}$ In Citizens United, the Supreme Court decided that political spending is protected by the free speech clause of the constitution. It determines that, "outside of a few very specialized contexts, such as political spending by foreign nationals", the prevention of "quid pro quo" corruption is the only legitimate basis for "regulating political contributions and expenditures" (Fein 2018: 374). Citizens United thus "severely restricts the range of options for campaign finance reform at the legislative and regulatory level" (Sitaraman 2018: 217).
} 
current constitutional law and what an overwhelming majority of citizens think is required to improve the democratic quality of their polity in favour of the latter.

The two reform options that would work within the confines of the current jurisdiction differ most obviously regarding their addressees, namely political candidates on the one hand (b) and corporations on the other (c). That difference is relevant to the extent that the reform options attribute responsibility to counter the influence of money differently, and to the extent that they contribute differently to other debates about possible directions for political change. Both reform options would curtail the influence of money on politics, albeit through different means, but each is likely to have political effects beyond that particular purpose. Where political actors mobilise for (b), they politicise practices of political campaigning and push the ethics of political campaigning onto the political agenda, which might fuel political debates on related topics such as transparency rules or regulations of microtargeting. Where political actors mobilise for (c), they seek reforms that would not only render corporate political spending more accountable. If corporations were transformed into stakeholder organisations, the problem of unequal political responsiveness might also be tackled from a different direction: where corporations are transformed into democratic spaces, more people, including those from lower socioeconomic strata, are involved in political activities of articulating grievances, which might translate into broader political participation more generally. That means that, although it may begin as a campaign finance reform, the corporate reform path could also tackle unequal political responsiveness through a strategy of empowerment.

By clarifying differences of possible reform paths such as those dealt with here, political theorists can provide orientation for future political debates on campaign finance reform. I am neither suggesting that the differences I have highlighted are the most important implications of the considered reform measures, nor that it is clear what would follow from them in terms of the decisions of political actors who search for suitable campaign finance reform measures to counteract the influence of money on politics. For instance, the fact that the constitutional amendment solution would manifest the primacy of democratic sovereignty in the sense described above might be seen as an advantage of that reform path in a situation that is increasingly shaped by a lack of confidence in the capacity of democratic institutions to represent people's preferences and implement policies that reflect these preferences. However, political actors might prefer, possibly for strategic reasons, reform measures that can be implemented faster and more easily than a constitutional amendment, or they might prefer a reform measure that has the additional benefit of creating new democratic spaces, especially if the democratisation of social relationships is part of their political agenda more generally.

Although the sort of contextual political theorising that I have illustrated does not determine one particular reform measure as superior over others, it can help illuminate the considered judgements of political actors in the relevant context. By clarifying the meaning of possible reform measures and exposing and ordering what might be their implications, political theorists might enrich, nuance or reorient prevalent perceptions of possibilities for reform and the perspectives of political actors who must decide what reform options they want to advocate if they wish to push the debate on campaign finance reform forward. What is specific about transformative contextual realism is less that it produces considerations that might illuminate people's practical judgements - obviously, that is what many political theories, realist and non-realist, aim at - and more the distinct way in which it does so. It 
discusses particular sorts of reform options, i.e. those that appear attractive in light of a critique of the status quo using particular sorts of contextual normative resources as described, and it discusses such options in a way that acknowledges that decisions on which reform option fits best must be made by those who are involved in the relevant political practices.

It might be asked if it actually needs political theorists to make the sort of contributions to debates on possibilities to transform the status quo that I have described. Could wellinformed persons, including non-academics, not deliver something very similar? I would answer that question in a way that echoes Jonathan Wolff's position (Wolff 2020: 268). It is not the case that political theorists produce arguments that could not be made by other considered, well-informed people. But political theorists are especially well-trained to make distinctions, ask questions, consider the merits of arguments, and analyse political phenomena. By using their professional skills to develop considerations on what it might mean politically to pursue one reform path rather than another in a given situation, transformative contextual realists can offer people potentially novel perspectives, encourage them to consider neglected possibilities for reform, or help them form preferences on the basis of their political ideals and policy goals and in light of the particular political circumstances that they face. If the relevant arguments could, in principle, also be made by non-academics, I would consider that a strength of the approach because, after all, that would mean that transformative contextual realists had succeeded in doing a sort of political theory that has a considerable capacity to connect to the very practices that they seek to guide.

The objectives of transformative contextual realism have some proximity to "engaged philosophy", which Jonathan Wolff describes as a form of philosophy that starts "from an understanding of the policy dilemma in front of us" and moves to "a consideration of policy options, which are to be evaluated, and a choice or recommendation made" (Wolff 2020: 268; see also Wolff 2019). Clearly, transformative contextual realism and engaged philosophy share the objective of providing orientation for policy debates, although transformative contextual realism does so by clarifying the meaning of different possible reform measures and by ordering their implications rather than by recommending concrete choices. There are further differences. Wolff's emphasis on the combination of understanding, evaluation and orientation in engaged philosophy mirrors Geuss's (2008) argument about the central tasks of political theory. I want to close my portrayal of transformative contextual realism by highlighting that it, too, represents an interpretation of what it might mean to combine understanding, evaluation and orientation, but one that differs from that of engaged philosophy in significant respects.

Engaged philosophy starts by seeking understanding of the nature of concrete policy dilemmas, i.e. situations in which decisions must be made on how to regulate policy fields such as railway safety, crime, or health care (Wolff 2020: 1), including the relevant state of regulation and public debates (Wolff 2020: 268). Transformative contextual realism, by contrast, starts by seeking understanding of the normative ideas behind relevant dynamics of political change. While engaged philosophy evaluates concrete policy options, transformative contextual realism evaluates the social and political arrangements in a given situation, such as the institutions of political decision-making. The reform measures that transformative contextual realists consider must be suitable to overcome or at least mitigate the identified deficiencies of the status quo, but it is the evaluation of the social and political arrangements in a given situation that determines what reform measures are selected for consideration in the first place. 
This brief comparison shows two things. First, transformative contextual realism should be of interest not only to realists who think that contributing to public policy debates is an important task for realist political theory (e.g. Raekstad 2021; Williams 2005: 139 ff.), but also to other political theorists who might not identify as members of the realist family, but seek to intensify political theory's engagement with actual politics. Second, its distinct interpretation of what it might mean for theorists to interrelate understanding, evaluation and orientation should render transformative contextual realism a particularly attractive form of political theory for radical realists. It is precisely by evaluating social and political forms on the basis of normative ideas that have been contributing to dynamics of political change that transformative contextual realism can produce potentially fundamental criticisms of the status quo, including criticisms of the shape of political processes that determine, to some important extent, what policy options make it to the agenda of political decision-making in the first place.

\section{Defending Transformative Contextual Realism}

A potential concern might be that transformative contextual realism purchases its capacity to guide a critique of the status quo at the cost of moralist argumentation. There might be two variants of that concern. First, it might be argued that transformative contextual realism is moralist in the sense that it prioritises particular contextual normative resources. The bias of decision-making processes appears problematic if assessed on the basis of the democratic principle, but the outcome might look different if other normative resources of the contexts of western democracies were made the basis of the assessment, such as individual liberty, economic prosperity, or peace and stability. Does the choice to make the democratic principle the basis of an evaluation of the status quo not reflect the moralist choice to prioritise a particular normative resource? Second, it might be asked if transformative contextual realism is insufficiently realist in the sense that it discusses reform options that are difficult to implement. Overturning Citizens United or democratising corporate governance structures might be effective means to curtail the role of money in politics, a critic might argue, but the considerable political efforts that would be needed to put these reforms in place render them unrealistic.

My response to the first variant of the objection is twofold. On the one hand, it would cast into doubt the realist nature of the proposed form of doing political theory only if realism were aimed at avoiding references to moral considerations. I stressed at the beginning of the article that this is not the case. The nub of the endeavour to do political theory in a realist vein is to develop normative arguments through engagements with political practice, not to avoid all moral considerations. Transformative contextual realism engages with actual practices at each step of the outlined proceeding: it evaluates the status quo on the basis of normative resources that characterise the context in question, and it begins its theorising of possible alternatives to the status quo with a consideration of demands for change that are put forth by people in that context. Because contextual transformative realists are interested in normative resources of a particular sort, i.e. in those that have been guiding critical engagements with social and political forms in a particular context, and because there should often be more than just one normative idea or principle that falls into that category, they do not take a purely descriptive stance on the relevant context (whatever exactly that 
would mean). But even if the choice to make a particular normative resource the basis of an evaluation of the status quo involved some moral considerations, that would not suffice to charge transformative contextual realism with moralism, given that avoiding moral considerations altogether is not what renders normative argumentation non-moralist for realists.

In addition, I want to question the view that the choice to evaluate the status quo on the basis of a particular contextual normative resource, which is the democratic principle in my illustration of contextual transformative realism, hinges on the moral premise about the general superiority of that particular contextual normative resource over others. The current situation in western democracies is characterised by a widespread dissatisfaction with the conditions of democratic institutions and the performance of political elites, which is, among other things, one of the major causes of the recent electoral successes of authoritarian populists (e.g. Berman 2019; Hawkins et al. 2017; Schäfer and Zürn 2021). Considering reform options that could help revive the democratic promise that the social order can continuously be criticised and reshaped might be necessary, not because the democratic principle is the generally superior normative resource of the context of western democracies, but because such reforms could help avert the potential threat to stability that western democracies might face if people's dissatisfaction with the current state of their democracies continues or intensifies.

As far as the second variant of the objection is concerned, it is important to bear in mind that realism is not limited to political ideas and proposals that are easily implemented (e.g. Cozzaglio and Favara 2021; Raekstad 2018, 2020; Rossi 2019). Realist proposals must make sense to people here and now, to use Williams's formulation, and they must be feasible. It is far from easy to determine what is feasible and what is not, and radical transformative events like revolutions demonstrate that what is considered feasible at a given point in time can quickly be outpaced by political developments. In his discussion of possible contributions of realist political theory to public policy debates, Raekstad (2021) shows that radical policy proposals, such as a proposal for a global tax on capital, can be permissible even if rather strict feasibility constraints are applied, i.e. if it is assumed that realist policy proposals must be compatible with the basic political and economic structure of a society, that they must not "too strongly contradict the entrenched interests of particularly powerful groups", and that they must be capable of attaining "a sufficient level of perceived legitimacy" (Raekstad 2021: 7).

I cannot go into much detail here, but I want to point out that there is little reason to suspect that the reform options that I have discussed in this article violate these criteria. Constitutional amendments require complex political and legal procedures, but they are a regular possibility in the current political system and have been implemented in a range of other cases. Examples like the German codetermination system or existing cooperatives illustrate that corporations can "import democratic norms within their governance structure" (Greenfield 2018: 241-242) and nevertheless function in the current economic system (e.g. Frega et al. 2019: 8). Although it would be naïve to think that all powerful groups in society will welcome the implementation of reform measures such as the ones I have discussed, it would also be implausible to assume that it could not be attractive to at least some of them to advocate such proposals. If campaign finance reforms, possibly alongside additional measures against the unequal political responsiveness in western democracies, can help mitigate the widespread frustration with the performances of democratic institutions, political and economic elites that have an interest in the stability of the current system might want to 
support or at least not work against attempts to implement such reforms. What is more, the reform options that I have outlined are capable of attaining a sufficient level of perceived legitimacy. Because an overwhelming majority of citizens already think that the influence of money on politics must be reduced, legislators who promote reform proposals that might achieve such a reduction can count on broad support from citizens. In fact, because transformative contextual realism begins its theorising of possible alternatives to the status quo by considering demands for change that are broadly shared in the relevant context, it represents a way of doing political theory that is eminently suited to shedding light on reform measures that have a particular capacity to attain a considerable level of perceived legitimacy.

An entirely different objection against transformative contextual realism might be raised by radical realists concerned that transformative contextual realism remains too wedded to the status quo, because it leaves the belief systems that underlie social and political relationships untouched. As the meaning that is attributed to concepts in a given context influences how people think and act, a truly critical engagement with the status quo should tackle the dominant uses of concepts, such as 'property', 'politics' or 'democracy', and enable novel forms of political thinking by probing the epistemic flaws of these uses (Prinz and Rossi 2017: 359-360).

I concede that this potential objection points to real limits of the proposed approach. But it does not call into question the value of transformative contextual realism as a novel possibility for doing realist political theory. The fact that it grounds its critique of the status quo on normative ideas that have been guiding critical engagements with social and political forms in a particular context, as well as on demands for change that people support on the basis of the normative and epistemic frameworks that influence their thinking here and now, endows transformative contextual realism with a distinct strength: it connects to how people think of themselves and their social environment in their current circumstances, rendering it particularly well-suited to contribute to an exploitation of a potential for change that is already there. Critics of ideology might unlock a different, possibly more extensive potential for change by contributing to transformations of political thinking that might inspire more radical political transformations of the status quo. However, whatever such transformations might look like, they are postponed to a more or less distant future, because they can only take place once the novel thinking that ideology critique enables has disseminated into at least substantial parts of society.

Thus, in addition to its capacity to contribute to constructive critique, transformative contextual realism has a second advantage over ideology critique, which is the immediacy with which it relates to people's views here and now. Because the downside of that immediacy is that transformative contextual realists might be ill-equipped to consider how ideological hegemonies limit and tame the imagination of political change, those who want to emancipate realist political theory from the status quo might do well to treat ideology critique and transformative contextual realism not as mutually exclusive alternatives but as potentially complementary interpretations of what it might mean to do radical realist political theory.

Clearly, more work is needed to flesh out the idea of transformative contextual realism. At least two methodological issues must be elaborated. The first is the selection of contextual normative resources. I have used the democratic principle as a prime example of a contextual normative resource that has been guiding critical engagements with social and political forms. However, it should be asked what alternatives might be on the table and how transformative contextual realists should decide which resource they tap into when faced 
with a broader range of potentially suitable normative resources. The second aspect that must be elaborated is the use of empirical material. Contextual transformative realists rely on empirical material to identify both problematic elements of the status quo and demands for change that are widely shared in the considered contexts. I have given examples in this article, but it would be important to specify what kind of empirics might be particularly relevant for addressing these tasks, and how transformative contextual realists engage with them. These methodological issues do not exhaust the agenda for future work on transformative contextual realism, but elaborating them would enable realists to further explore how transformative contextual realism can enrich the undertaking of radical realist political theorising.

Acknowledgements I would like to thank Carlo Burelli, Ilaria Cozzaglio, Chiara Destri, Eva Erman, Greta Favara, Jonathan Leader Maynard, Enzo Rossi, and all other participants of the 'Political Normativity: Realism Meets Critics' workshop held at the University of Milan in October 2019, for a helpful discussion on contextual argumentation in political realism. I presented a different paper on the topic at the workshop, but the comments I received were also immensely helpful for my work on this article. I also want to thank Janosch Prinz and Ulrich Willems for various exchanges on contextual realism and status quo critique, and the two anonymous referees for their recommendations for improvements of the article.

Funding Open Access funding enabled and organized by Projekt DEAL.

Competing Interests The author has no competing interests to declare that are relevant to the content of this article.

Open Access This article is licensed under a Creative Commons Attribution 4.0 International License, which permits use, sharing, adaptation, distribution and reproduction in any medium or format, as long as you give appropriate credit to the original author(s) and the source, provide a link to the Creative Commons licence, and indicate if changes were made. The images or other third party material in this article are included in the article's Creative Commons licence, unless indicated otherwise in a credit line to the material. If material is not included in the article's Creative Commons licence and your intended use is not permitted by statutory regulation or exceeds the permitted use, you will need to obtain permission directly from the copyright holder. To view a copy of this licence, visit http://creativecommons.org/licenses/by/4.0/.

\section{References}

Arlen G, Rossi E (2021) Must Realists Be Pessimists About Democracy? Responding to Epistemic and Oligarchic Challenges. Moral Philos Politics 8(1):27-49

Berman S (2019) Populism is a Symptom Rather than a Cause: Democratic Disconnect, the Decline of the Center-Left, and the Rise of Populism in Western Europe. Polity 51(4):654-667

Cozzaglio I, Favara G (2021) Feasibility beyond Non-ideal Theory: A Realist Proposal. Ethical Theory Moral Pract (online first) https://doi.org/10.1007/s10677-021-10206-3

Cross B (2020) Radicalizing realist legitimacy. Philos Soc Crit 46(4):369-389

Elsässer L, Hense S, Schäfer A (2018) Government of the People, by the Elite, for the Rich: Unequal Responsiveness in an Unlikely Case. MPIfG Discussion Paper 18(5):1-16

Erikson RS (2015) Income Inequality and Policy Responsiveness. Annu Rev Polit Sci 18:11-29

Erman E, Möller N (2015) Political Legitimacy in the Real Normative World: The Priority of Morality and the Autonomy of the Political. Br J Polit Sci 45(1):215-233

Erman E, Möller N (2018) Political Legitimacy for Our World: Where Is Political Realism Going? J Politics $80(2): 525-538$

Fein RA (2018) Fixing the Supreme Court's Mistake: The Case for the Twenty-Eighth Amendment. In: Mazo ED, Kuhner TK (eds) Democracy by the People. Reforming Campaign Finance in America. Cambridge University Press, Cambridge, pp 369-398

Finlayson L (2017) With radicals like these, who needs conservatives? Doom, gloom, and realism in political theory. Eur J Political Theory 16(3):264-282 
Floyd J (2011) From historical contextualism, to mentalism, to behaviourism. In: Floyd J, Stears M (eds) Political Philosophy versus History? Contextualism and Real Politics in Contemporary Political Thought. Cambridge University Press, Cambridge, pp 38-64

Floyd J (2017) Is Political Philosophy Impossible? Thoughts and Behaviour in Normative Political Theory. Cambridge University Press, Cambridge

Floyd J (2020) Normative behaviourism as a solution to four problems in realism and non-ideal theory. Crit Rev Int Soc Political Philos 23(2):137-162

Frega R, Herzog L, Neuhäuser C (2019) Workplace democracy-The recent debate. Philosophy Compass 14(4):1-11

Galston WA (2010) Realism in political theory. Eur J Political Theory 9(4):385-411

Geuss R (2008) Philosophy and Real Politics. Princeton University Press, Princeton

Gilens M (2005) Inequality and Democratic Responsiveness. Public Opin Q 69(5):778-796

Greenfield K (2018) Constraining and Channeling Corporate Political Power in Trump's America. In: Mazo ED, Kuhner TK (eds) Democracy by the People. Reforming Campaign Finance in America. Cambridge University Press, Cambridge, pp 240-260

Hall E, Sleat M (2017) Ethics, morality and the case for realist political theory. Crit Rev Int Soc Political Philos 20(3):278-295

Hawkins KA, Read M, Pauwels T (2017) Populism and Its Causes. In: Rovira Kaltwasser C, Taggart P, Ochoa Espejo P, Ostiguy P (eds) The Oxford Handbook of Populism. Oxford University Press, Oxford, pp 267-286

Horton J (2010) Realism, Liberal Moralism and a Political Theory of Modus Vivendi. Eur J Political Theory $9(4): 431-448$

Horton J (2019) Modus Vivendi and Political Legitimacy. In: Horton J, Westphal M, Willems U (eds) The Political Theory of Modus Vivendi. Springer, Cham, pp 131-148

Jubb R (2015) The Real Value of Equality. J Politics 77(3):679-691

Jubb R (2017) Realism. In: Blau A (ed) Methods in Analytical Political Theory. Cambridge University Press, Cambridge, pp 112-130

Jubb R (2019) On What a Distinctively Political Normativity Is. Political Stud Rev 17(4):360-369

Laclau E, Mouffe C (2001) Hegemony and Socialist Strategy. Towards a Radical Democratic Politics, 2nd edn. Verso, London/New York

Leader Maynard J, Worsnip A (2018) Is There a Distinctively Political Normativity? Ethics 128(4):756-778

Mazo ED, Kuhner TK (2018a) Democracy by the Wealthy: Campaign Finance Reform as the Issue of Our Time. In: Mazo ED, Kuhner TK (eds) Democracy by the People. Reforming Campaign Finance in America. Cambridge University Press, Cambridge, pp 1-16

Mazo ED, Kuhner TK (2018b) (eds) Democracy by the People. Reforming Campaign Finance in America. Cambridge University Press, Cambridge

McCormick JP (2011) Machiavellian Democracy. Cambridge University Press, Cambridge

McQueen A (2017) Political Realism and the Realist 'Tradition'. Crit Rev Int Soc Political Philos 20(3):296-313

McQueen A (2019) Political Realism and Moral Corruption. Eur J Political Theory 19(2):141-161

Newey G (2001) After Politics: The Rejection of Politics in Contemporary Liberal Philosophy. Palgrave, Basingstoke

Peters Y, Ensink SJ (2015) Differential Responsiveness in Europe: The Effects of Preference Difference and Electoral Participation. West Eur Politics 38(3):577-600

Philp M (2012) Realism without Illusions. Political Theory 40(5):629-649

Prinz J (2016) Raymond Geuss' radicalization of realism in political theory. Philos Soc Crit 42(8):777-796

Prinz J (2020) Realism in Political Theory, Ethnographic Sensibility, and the Moral Agency of Bureaucrats. Polity 52(1):64-87

Prinz J, Rossi E (2017) Political realism as ideology critique. Crit Rev Int Soc Political Philos 20(3):348-365

Raekstad P (2018) Realism, Utopianism, and Radical Values. Eur J Philos 26(1):145-168

Raekstad P (2020) Realism, Utopianism and Human Rights. Political Stud Rev 18(4):542-552

Raekstad P (2021) The Model of the Legislator: Political Theory, Policy, and Realist Utopianism. Contemp Political Theory (online first) https://doi.org/10.1057/s41296-021-00469-X

Rossi E (2010) Reality and imagination in political theory and practice: On Raymond Geuss's realism. Eur J Political Theory 9(4):504-512

Rossi E (2019) Being Realistic and Demanding the Impossible. Constellations 26(4):638-652

Rossi E, Sleat M (2014) Realism in Normative Political Theory. Philosophy Compass 9/10:689-701

Schäfer A, Zürn M (2021) Die demokratische Regression. Die politischen Ursachen des autoritären Populismus. Suhrkamp, Berlin 
Sitaraman G (2018) The People’s Pledge: Campaign Finance Reform without Legal Reform. In: Mazo ED, Kuhner TK (eds) Democracy by the People. Reforming Campaign Finance in America. Cambridge University Press, Cambridge, pp 201-219

Sleat M (2013) Liberal Realism. A Realist Theory of Liberal Politics. Manchester University Press, Manchester

Sleat M (2014) Legitimacy in Realist Thought: Between Moralism and Realpolitik. Political Theory 42(3):314-337

Sleat M (2016) What is a Political Value? Political Philosophy and Fidelity to Reality. Soc Philos Policy 33(1-2):252-272

Thomas A (2017) Rawls and political realism: Realistic utopianism or judgement in bad faith? Eur J Political Theory 16(3):304-324

Westphal M (forthcoming) For an Agonistic Element in Realist Legitimacy. Soc Theory Pract

Williams B (2005) In the Beginning Was the Deed. Realism and Moralism in Political Argument. Princeton University Press, Princeton

Wolff J (2019) Method in philosophy and public policy. Applied philosophy versus engaged philosophy. In: Lever A, Poama A (eds) The Routledge Handbook of Ethics and Public Policy. Routledge, Abingdon/ New York, pp 13-24

Wolff J (2020) Ethics and Public Policy. A Philosophical Inquiry. 2nd edn. Routledge, Abingdon and New York

Publisher's Note Springer Nature remains neutral with regard to jurisdictional claims in published maps and institutional affiliations. 